\title{
CONIDIOGENESIS OF DETERIORATED VARIANT OF THE STRAIN Abnc OF Aspergillus nidulans
}

\author{
Ágata Cristiane Huppert Giancoli ${ }^{1}$; Aline Aparecida Pizzirani-Kleiner ${ }^{2 *}$ \\ ${ }^{1}$ USP/ESALQ - Programa de Pós-Graduação em Genética e Melhoramento de Plantas - Depto. de Genética, \\ C.P. 83 - 13400-970 - Piracicaba, SP - Brasil. \\ ${ }^{2}$ USP/ESALQ - Depto. de Genética. \\ *Corresponding author <aapklein@esalq.usp.br>
}

\begin{abstract}
The Abnc strain of $A$. nidulans carries the bncA1 gene (binucleated conidia), which induces the formation of binucleate and trinucleate conidia, displaying a chromosome I duplicated area and shifted to the chromosome II (I $\rightarrow$ II), and bringing forth genetic instability with degenerated sectors. This work has considered in a cytological level the conidiogenesis of the deteriorated variants isolated from the Abnc strain of $A$. nidulans, observing the event at the level of structural alterations, which composes the conidiophore, and the variations in the number of sterigmata and conidia nuclei. Cytogenetic analyses of conidiogenesis were accomplished in predetermined periods, under Giemsa stain, to observe the nuclei and analysis through the Scanning Electronic Microscopy, and also the structures that composes the conidiophore. The analyzed, deteriorated variants presented alterations in the cell-foot, metulae and phialides structure, conidiophore number and conidias reduction, and the formation of secondary conidiophores. These alterations can be related to genes for the development, bristle, and activities of NIMA e NINX ${ }^{\text {cdc2 }}$ (involved in morphogenesis regulatory cycle) that induce the expression of brislte, establishing the link to the regulation and expression of the genes control throughout the conidiophore development.
\end{abstract}

Key words: bristle, conidiophore, developmental mutants

\section{CONIDIOGÊNESE DE VARIANTES DETERIORADOS DA LINHAGEM Abnc DE Aspergillus nidulans}

\begin{abstract}
RESUMO: A linhagem Abnc de A. nidulans é portadora do gene bncA1 (“binucleated conidia”), que confere a característica de conídios bi e trinucleados, além de apresentar uma região duplicada do cromossomo I e translocada para o cromossomo II (I $\rightarrow$ II), gerando instabilidade genética com formação de setores deteriorados. Este trabalho analisou citologicamente a conidiogênese dos variantes deteriorados isolados da linhagem Abnc de $A$. nidulans, observando a ocorrência de alterações das estruturas que compõe o conidióforo e as variações no número de núcleos dos esterígmas e conídios. As análises citogenéticas da conidiogênese foram realizadas com períodos pré-determinados, sendo efetuada a coloração de Giemsa para observação dos núcleos, e análise por Microscopia Eletrônica de Varredura, para observação das estruturas que compõe o conidióforo. Os variantes deteriorados analisados apresentaram alterações na estrutura das células-pé, métulas e fiálides, redução do número de conidióforos e conídios, e formação de conidióforos secundários. Estas alterações no conidióforo podem estar relacionadas com os genes para o desenvolvimento, bristle e com atividade das proteínas NIMA e NINX ${ }^{\text {cdc2 }}$ (envolvidas com o ciclo regulatório da morfogênese) as quais induzem a expressão de brislte, estabelecendo o caminho para a regulação e controle da expressão dos genes durante o desenvolvimento do conidióforo.

Palavras chave: bristle, conidióforo, mutantes para o desenvolvimento
\end{abstract}

\section{INTRODUCTION}

The fungus Aspergillus nidulans presents a life cycle three phases, Vegetative Cycle, Asexual Cycle or Conidiogenesis and Sexual Cycle or Ascosporogenesis. The vegetative growth begins with the spore germination that can be a conidia or an ascospore (Lee \& Adams, 1994). The ramified air hyphae differs in a conidiophore, a generative structure of the asexual cycle (Adams et al., 1998). This differentiation and development process constitute the Conidiogenesis. The conidiophore morphology shows five development stages (Mims et al., 1988): (i) transformation of a hyphae cell in a cell-foot, the structure that maintains and develops the conidiophore; (ii) cell-foot differentiation in the conidiophore stem, and apex's gradual enlargement, creating a vesicle with several nuclei; (iii) metulae come out as protuberances in the intern surface of the vesicle wall, with nuclear migration from the vesicle apical area to metulae, making it uninucleated and after that occurring a mitosis; (iv) the phialides are formed in metulae apex with nucleus-son migration from metulae to phialides; (v) formation of the 
phialides apex original primary conidia and arranging conidia chains (Oliver, 1972; Bergen \& Morris, 1983).

The structural and temporal development processes are controlled by groups of regulatory genes and the activation sequence involves the genes bristle ( $b r l \mathrm{~A})$, abacus $(a b a \mathrm{~A})$ and wet-white (wet $\mathrm{A})$, establishing the regulatory pathway and genes expression control during the conidiophore development (Adams et al., 1998). Other two genes, stund (stuA) and medusa (medA), interact with the regulators genes (Miller, 1990; Miller et al., 1992).

The strain A of $A$. nidulans, with double chromosome segment (chromosome I) and transferred (chromosome II) (Nga \& Roper, 1968; 1969) presents mitotic instability, which leads to deteriorated sections from total or partial loss of the chromosomic duplication, with subsequent insert of that segment in any of the eight groups of junction of $A$. nidulans (Azevedo \& Roper, 1970). Several factors affect the genetic instability: chemical factors, as the caffeine (Azevedo \& Santana, 1975), physical factors, such as temperature (Lieber, 1976), and genetic factor, such as the effect of the bncA1 gene, that originates conidia bi and trinucleted (Pizzirani-Kleiner \& Azevedo, 1986a, 1994b; Pascon, 1994) and reduce the mitotic instability in the Abnc strain, with an increase in the frequency of deteriorated sections (Pascon, 1994). The bncAl gene causes abnormalities during the formation of the conidiophore such as the reduced number and phialides and metulae septa (Pascon et al., 2001).

This article presents the study of the conidiogenisis of the deteriorated variants originated from the Abnc strain of $A$. nidulans. Structural and temporary alterations were observed in the conidiophore of the deteriorated variants, VB7, VB8, VB9, VB10 and VB11. These structural alterations present structural likeness with mutants bristle.

\section{MATERIAL AND METHODS}

\section{Strains}

The MSE of $A$. nidulans strain belongs to the Glasgow (England) stock, and presents the marks $w \mathrm{~A} 3$ (II), facA303 (V), galA1 (III), yA1(I), pyroA4 (IV), sB3 (VI), nicB6 (VII) and riboB2 (VIII) (McCully \& Forbes, 1965). The deteriorated variants VB7, VB8, VB9, VB10 and VB11 were isolated in the laboratory of Microorganisms of Genetics (USP/ESALQ) out of spontaneous Abnc strain sections which present the marks proA1 (I), pabaA6 (I), Dp (I-II), and the bncA1 gene (IV), that generates conidia bi and trinucleated (Pizzirani, 1977).

\section{Medium Culture and Conidiogenesis.}

Conidia of the VB 7, VB8, VB9, VB10 and VB11 strain were incubated in complete medium (Pontecorvo et al., 1953), and over dialysis membranes and subsequent incubation at a temperature of $37^{\circ} \mathrm{C}$ for 20,32 and $72 \mathrm{~h}$ (Giancoli, 2000).

\section{Stain of nucleus and optical microscopy}

After the established periods, the coverslips with adherent hyphae were transferred to etanol and acetic acid, lactic acid solution (6:1:1), and incubated at room temperature for $15 \mathrm{~min}$. Then, coverslips were incubated for $12 \mathrm{~min}$. at $63^{\circ} \mathrm{C}$ in $1 \mathrm{~mol} \mathrm{~L}^{-1} \mathrm{HCl}$ solution, rinsed in distilled water and transferred to $100 \mathrm{mmol} \mathrm{L}^{-1}$ phosfhate buffer ( $\mathrm{pH}$ 7.0) for 1 hour, prior to staining after incubation for $20 \mathrm{~min}$. at room temperature in a Giemsa solution (Tanaka et al., 1979).

\section{Scanning Electron Microscopy (SEM)}

After the pre established periods the cover-slips adherent hyphae and conidiophores were transferred to glutaraldehyde $25 \%$ solution, paraformaldehyde $10 \%$ in caccodilate buffer $0.2 \% \mathrm{pH} 7.2$ and $\mathrm{CaCl}_{2} 0,1 \mathrm{~mol} \mathrm{~L}^{-1}$. After 1-2 hours the cove-rslips were washed for $10 \mathrm{~min}$ with buffer and post fixed to 1 hour in similarly buffered $1 \% \mathrm{OsO}_{4}$. Cover slips were then washed in distilled water and dehydrated in a graded acetone series. Cover slips were dried to a critical point (Balzers CPD 030), coated with gold (MED 010 - Balzers), and examined under a Scanning Electron Microscope (Leo 435 VP).

\section{RESULTS AND DISCUSSION}

Starting from 20 hours of cultivation MSE and Abnc strain, it was possible to observe indifferentiated hyphae, and in some cases differentiated hyphae in cell-foot with the stem of the conidiophore already formed. At 32 hours, ripe phialides with conidia development were detected. These data are similar to those reported by Axelrod et al. (1973) and Champe et al. (1981), demonstrated that the temporary and space development of the conidiophores occurred after 20 hours of cultivation. Starting from 72 hours, it was possible to observe the conidiophores with long conidia chains (Figures 1a and 1b). The Abnc strain bearing of the bncAl gene (Pizzirani-Kleiner, 1981), besides presenting conidia bi and trinucleated, shows other interesting aspects: the disposition of the conidia chains, where they are just found conidia chains uninucleated and or just binucleated, are rarely found mixed chains, what agrees with the observations obtained by Pascon (1994) and Pascon et al. (2001). The irregular organization of the metulae and phialides along the vesicle of the conidiophore, was noticed in a small number of structures when compared with the strains that don't show the mutation $b n c \mathrm{~A} 1$ (not given presented); the phialides are septate with until three nuclei in its interior (Figure 3a).

Clutterbuck $(1969 ; 1970 ; 1977)$ suggested classifications of the genes involved in the differentiation of the conidiophore in: Class I - mutants that affect the acquisition of the competence; and Classe II - mutants that 
affect the formation of the conidiophore and conidia, inside of the Classe II - are subdivided more four types of genes (bristle, abacus, stund and medusa). The bncA1 gene probably is into the mutants' categories with modification of the conidiophore (Miller et al., 1992; Pascon et al., 2001), which are combined by the genes stuA and medA, that cause specific alterations in the morphology and space organization of the conidiophore, but do not avid the conidia development

The deteriorated variants were produced with the approximate frequency of one in ten analyzed colonies (Giancoli, 2000). The deteriorated variants analyzed, VB7, VB8, VB9, VB10 and VB11 presented little conidiation and different degrees pigmentation.

The deteriorated variant VB7 presented time of compatible development with the pattern strain (MSE), with differentiation of the hyphae starting from 20 hours of development. The conidia's growth occurred within 32 hours, being observed small conidia chains uni and binucleated. VB7 presented a smaller amount of conidiophore if compared with the MSE strain. The temporary development of the conidiophore was late, the metulae and phialides demonstrated characteristic alterations, ob-
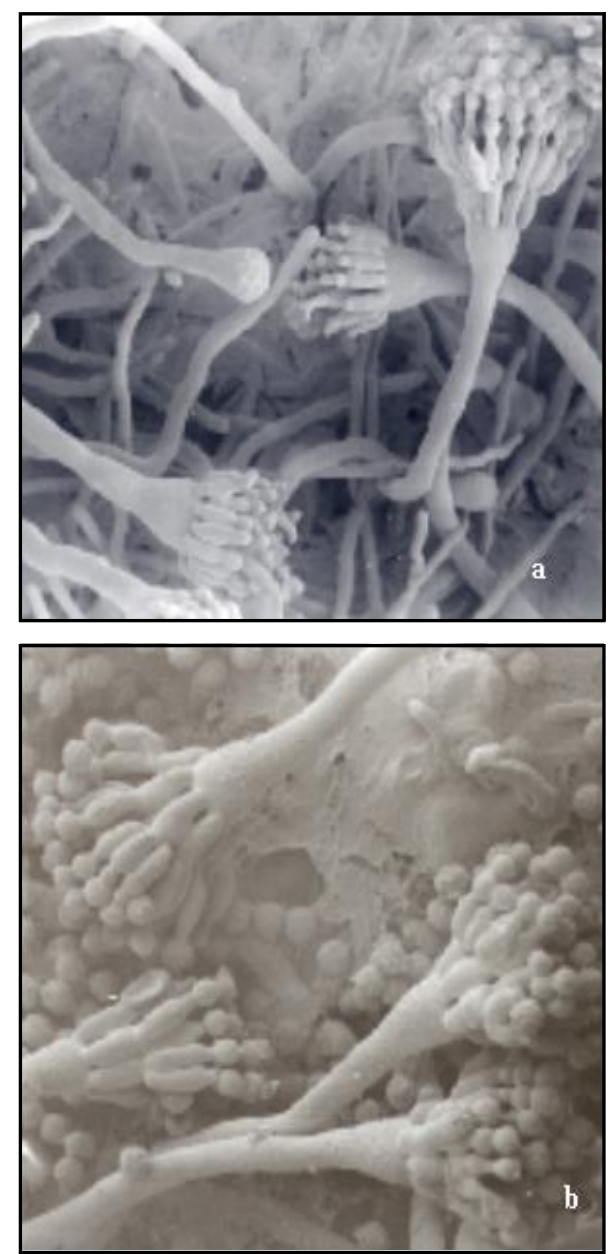

Figure 1 - MSE strain (a. $1000 \mathrm{x}$ ) and Abnc (b. $2000 \mathrm{x}$ ) A. nidulans, 72 hours of growth (SEM). served in the strain with the $b n c \mathrm{~A} 1$ gene (Figure $3 \mathrm{a}$ ). The metulae and phialides present extended and unlikely structures (Figure 2a) with lack of conidia. Normal conidiophores were observed. We could observe the formation of secondary conidiophore that is a characteristic of the bristle and medusa genes (Figure $2 \mathrm{~b}$ ).

The deteriorated variant VB8 has shown a space and temporary abnormal organization outstanding when compared to the other deteriorated variants. The hyphae differentiation, followed by the vesicles growth was observed starting from 32 hours. There was a characteristic abnormal spatial organization, with extended and unlikely metulae. (Figures 2c, 2d and 3b). Some vesicles present

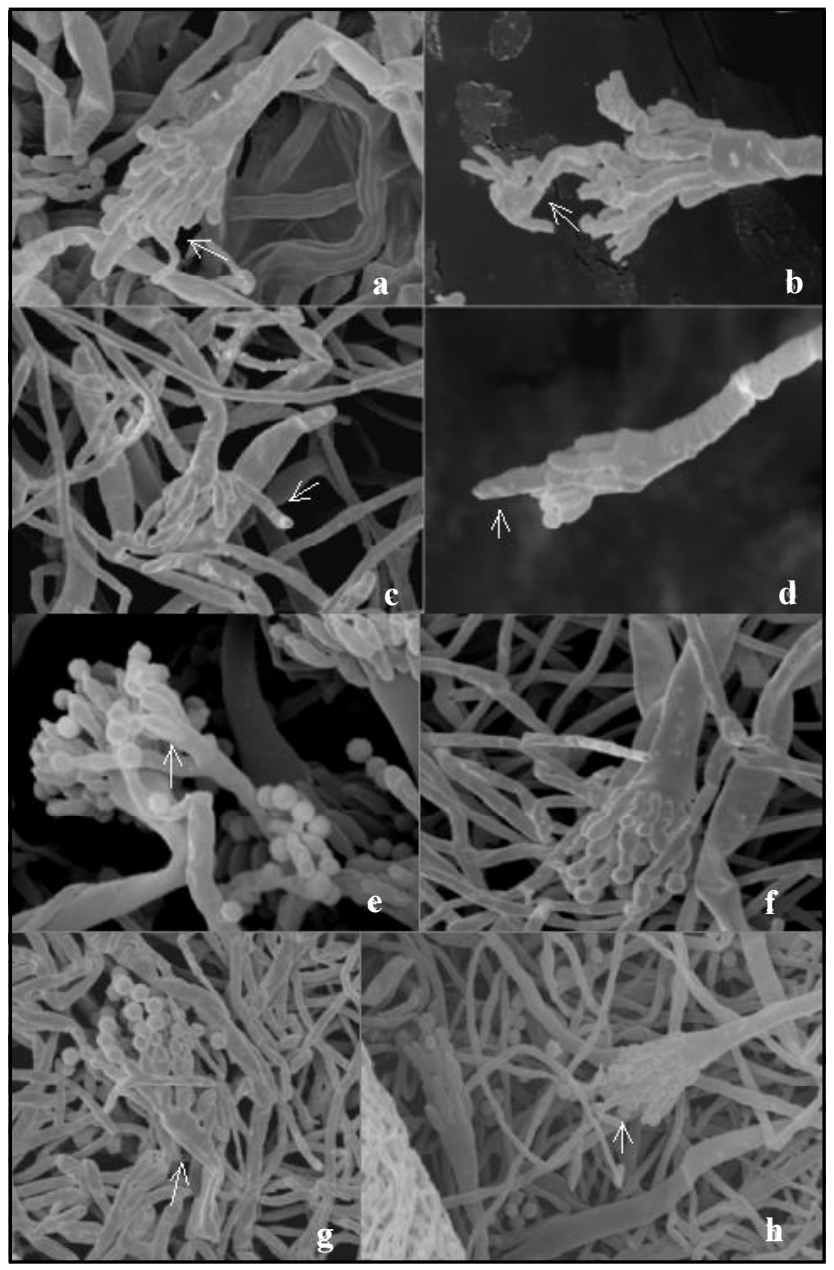

Figure 2 - SEM (a). VB7 sterigmata without differentiation, metulae and phialides prolonged after 32 hours of cultivation $(4600 \mathrm{x})$. (b). VB7 formation of secondary conidiophore with 72 hours of cultivation $(4500 \mathrm{x})$. (c, d) VB8 sterigmata without differentiation, metulae and phialide prolonged ofter 32 hours and 72 hours of cultivation respectively (4000 $\mathrm{x}$ and $5030 \mathrm{x}$ ). (e and f) VB9 and VB10 sterigmata without differentiation, metulae and phialides prolonged with 32 hours of cultivation ( $3580 \mathrm{x}$ and 3870 $\mathrm{x})$. ( $\mathrm{g}$ and $\mathrm{h})$. VB11 abnormality in the formation of the vesicle with of 72 hours of cultivation $(3110 \mathrm{x}$; h. VB11) sterigmata without differentiation, metulae and phialides prolonged with 72 hours of cultivation $(3140 \mathrm{x})$. 
irregularities in their formats and the amount of conidiophores are small. That deteriorated variant presented an extremely high number of hülle cells, when compared with the MSE strain (data not available).

The cytological analysis of VB9 presented likeness with VB7. The period of temporary development was similar to the established ones for the pattern strain. There was a characteristic abnormal spatial organization, with the extension and diferentiation for metulae (Figures 2a and $2 \mathrm{e}$ ). The amount of conidia is reduced. For carrying the mutation in the bncAl gene it presents septated and smaller amount of metulae and phialides. Normal conidiophores were observed.

The deteriorated variants VB 10 and VB11 presented great likeness. There was a delay in the process of temporary-spatial development of the conidiophore. In these deteriorated variants occurred abnormal spatial organization, with metulae extension (Figures 2f, $2 \mathrm{~g}$ and $3 \mathrm{~d}$ and $3 \mathrm{e})$. VB11 presented some vesicles with irregular format (Figure 2f). The beginning of the differentiation of the hyphae occurred about 32 hours and presented a reduced number of conidiophores.
The morphologic alterations observed in the structure of the conidiophore are characteristic for development genes. These genes should cause conidia alterations (wet $\mathrm{A})$; alterations in the conidiophore $(s t u \mathrm{~A}$ and medA), which don't affect the conidia formation; mutants that block the conidia formation ( $b r l \mathrm{~A}$ and $a b a \mathrm{~A})$ and mutants that affect the pigmentation of the conidia (ivoA and ivoB) (Timberlake \& Clutterbuck, 1994). The main characteristics of the conidiophore development are due to the central control of the bristle gene. However, the activation of the protein $\mathrm{Brl}$ is not well studied, but the occurrence of the interactions is known among the genes stu (stunted) and med (medusa). Ye et al. (1999) and Schier et al. (2001), while studying the relationship between the regulation of the cellular cycle and the morphogenetic development of $A$. nidulans, they noticed that exists a deep relationship between the two cycles, being the morphogeneses dependent of the increase of the quinase activity of NIMA and NINX ${ }^{\text {cdc2 }}$, so this way can occur the activation and regulation in cascade of genes, that take the normal formation of the conidiophore.

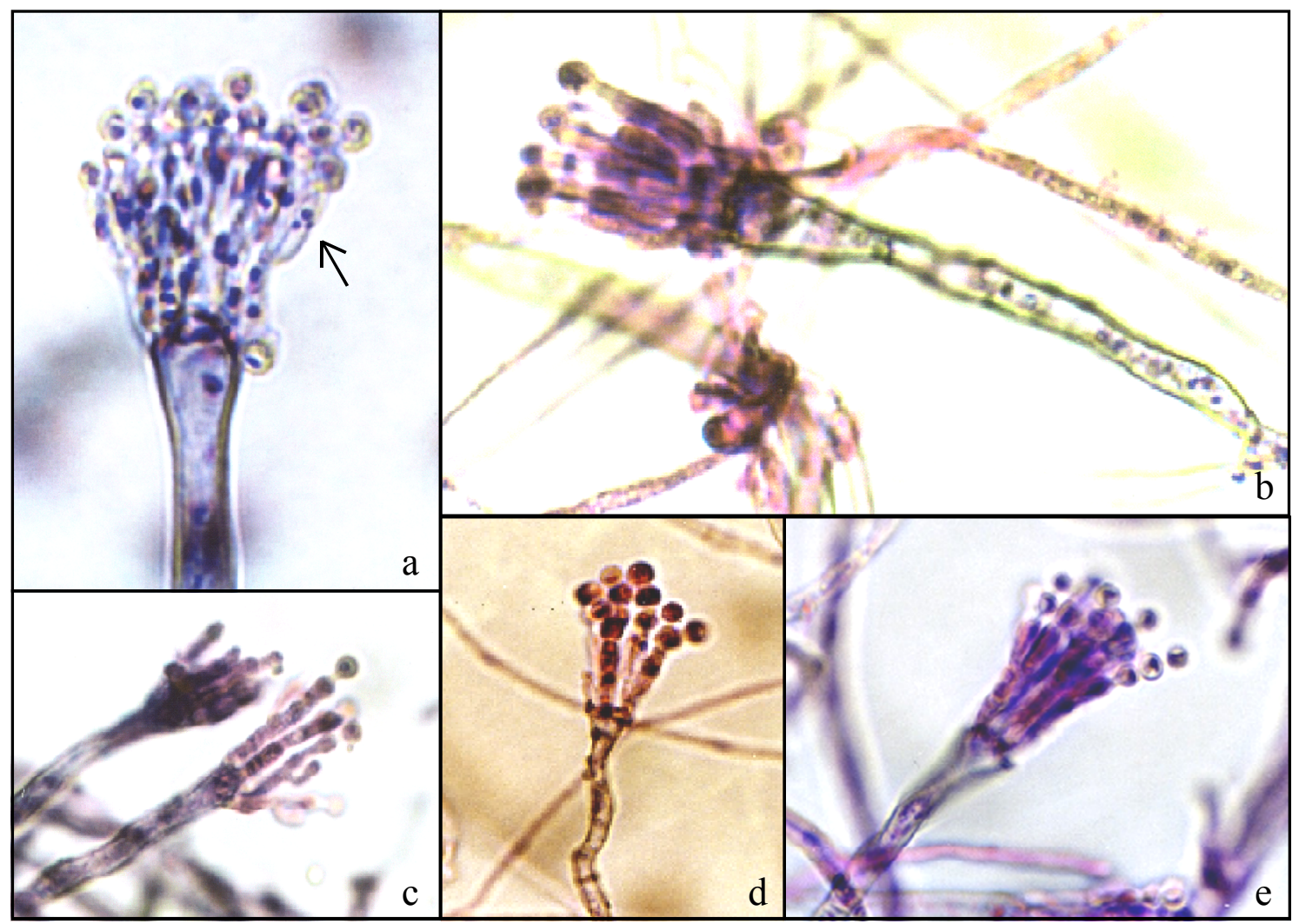

Figure 3 - Giemsa stain. (a). VB7 showing alteration in the nucleus number in phialides caused by the mutation bncA1, growth of 72 hours $(1200 \mathrm{x}) ;(\mathrm{b}, \mathrm{c}, \mathrm{d}, \mathrm{e}) \mathrm{VB} 8 \mathrm{VB} 9 \mathrm{VB} 10$ and VB11 respectively, sterigmata without differentiation, prolongated metulae and phialides, growth of 72 hours $(1200 \mathrm{x})$. 
The microscopic analyses resulted in the detection of abnormalities formation of the conidiophore, as the presence of secondary conidiophore starting from metulaes abnormal, besides extended metulae and phialide. This phenotype is characteristic so much of mutants light bristle or middleman (leaky) as of medula mutants. These last ones, however, present a pigment decrease of the conidiophore and metulae chains (Miller, 1993), two absent characteristics in the analyzed deteriorated variants.

In analyzing the intermediate conidiophore we always find morphological vesicles and metula alterations. Adams et al. (1998) observed that after the first synthesis of the protein Brl (BrlA), there is a differentiation of the vesicle and the germination of the metulae, so the only nuclei then migrate for the metulae and differentiation is concluded in an autonomous way. These results suggest that the amount of protein $\mathrm{Brl}$ that is aimed for each metulae altogether with the cytoplasm during its germination should induce the genes for the final stage of the fiálides differentiation. However, when there is little protein expression $\mathrm{Brl}$ in the vesicles, the metulae could receive an insufficient amount for the beginning of the induction, tending to an abnormal behavior, differentiating in a stem. This abnormal stem could originate a new secondary conidiophore. This interpretation would also justify the fact that some vesicles not present differentiated metulae, growing as secondary stem, beside differentiated metulae, with fialides and conidia. The synchronism lack can be the result of different amounts of protein Brl of each metulae. These observations indicate that the synchronism usually found in the differentiation of the structures of the conidiophore depend on the minimum of protein Brl produced in the vesicle, guaranteeing surpluses in the metulae, enough to control small deviations in the distribution of this product during the germination (Adams et al., 1998).

The cytological analyses suggest that the deteriorated variants present the characteristic phenotype of the bristle gene. However, these alterations can be influenced by regulatory genes of the cell cycle avoiding the correct activation of the bristle gene (Ye et al., 1999 and Schier et al., 2001). These were the first steps in the study of this group of deteriorated variants that are going along with the investigation at a molecular level.

\section{ACKNOWLEDGMENTS}

Dr. E. W. Kitajima and Dr. B. Leite for allow the execution of the observations of Scanning Electron Microscopy (SEM) in NAP/MEPA - ESALQ/USP.

\section{REFERENCES}

ADAMS, T.H.; WIESER, J.K.; YU, J.H. Asexual sporulation in Aspergillus nidulans. Microbiology and Molecular Biology Reviews, v.62, p.3554, 1998.
AXELROD, D.E.; GEALT, M.; PASTUSHOK, M.; Gene control of developmental competence in Aspergillus nidulans. Developmental Biology, v.34, p.9-15, 1973.

AZEVEDO, J.L.; ROPER, J.A. Mitotic non-conformity in Aspergillus nidulans: successive and transposable genetic changes. Genetical Research, v.16, p.79-93, 1970.

AZEVEDO, J.L.; SANTANA, E.P. The use of cloroneb to obtain haploid segregants from heterozygous diploid of Aspergillus nidulans. Aspergillus Newsletter, v.13, p.6, 1975.

BERGEN, L.G.; MORRIS, N.R. Kinetics of nuclear division cycle of Aspergillus nidulans. Journal of Bacteriology, v.156, p.155-160, 1983.

CHAMPE, S.P.; KURTZ, M.; YAGER, I.; BUTNICK, N.; AXELROD, D. Spore formation in Aspergillus nidulans: competence and other developmental processes. In: HOHL, H.R.; TURIAN, G (Ed.) The fungal spore morphogenetic control. New York: Academic Press, 1981. p.255276.

CLUTTERBUCK, J. A mutational analysis of conidial development in Aspergillus nidulans. Genetics, v.63, p.317-327, 1969.

CLUTTERBUCK, J. A variegated position effect in Aspergillus nidulans. Genetical Research, v.16, p.303-316, 1970.

CLUTTERBUCK, J. The genetics of conidiation in Aspergillus nidulans. In: PATERMAN, J.A.; SMITH, J.E. (Ed.) Genetics and physiology of Aspergillus. New York: Academic Press, 1977. p.305-317.

GIANCOLI, A.C.H. Caracterização citológica e genética de Linhagens de Aspergillus nidulans portadoras de duplicação cromossômica e do gene bncA1. Piracicaba: USP/ESALQ, 2000. 103p. (Dissertação - Mestrado).

LEE, B.N.; ADAMS, T.H. The Aspergillus nidulans flu $\mathrm{G}$ gene is required for production of an extracelular developmental signal. Genes and Development, v.8, p.641-651, 1994.

LIEBER, M.M. The effects of temperature on genetic instability in Aspergillus nidulans. Mutation Research, v.34, p.93-122, 1976.

McCULLY, K.S.; FORBES, E. The use of p-fluorphenilalanine with "master" strain of Aspergillus nidulans form assigning gene of to linkage groups. Genetical Research, v.6, p.352-359, 1965.

MILLER, B.L. The developmental genetics of asexual reproduction in Aspergillus nidulans. Developmental Biology, v.1, p.207-219, 1990.

MILLER, B. Brushing up on bristles: complex genes and morphogenesis in molda. Trends in Genetics, v.9, p.293-295, 1993.

MILLER, K.Y.; WU, J.; MILLER, B.L. Stu A is required for cell pattern formation in Aspergillus. Genes and Development, v.6, p.1770-1782, 1992.

MIMS, C.W.; RICHARDSON, E.A.; TIMBERLAKE, W.E. Ultrastructural analysis of conidiophore development in the fungus Aspergillus nidulans using freeze-substitution. Protoplasma, v.144, p.132-141, 1988.

NGA, B.H.; ROPER, J.A. Quantitative intrachromosomal changes arising at mitosis in Aspergillus nidulans. Genetics, v.5, p.193-209, 1968.

NGA, B.H.; ROPER, J.A. A system generation spontaneous in intrachromosomal changes at mitosis in Aspergillus nidulans. Genetical Research, v.14, p.63-70, 1969.

OLIVER, P.T. Conidiophore and spore developmental in Aspergillus nidulans. Journal of General Microbiology, v.73, p.45-54, 1972.

PASCON, R.C. Isolamento e caracterização de setores deteriorados da linhagem Abnc de Aspergillus nidulans. Piracicaba: USP/ESALQ, 1994 140p. (Dissertação - Mestrado).

PASCON, R.C.; PIZZIRANI-KLEINER, A.A.; MILLER, B.L. The Aspergillus nidulans bncA1 mutation causes defects en the cell division cycle, nuclear and developmental morphogenesis. Molecular and General Genetics, v.264, p.546-554, 2001.

PIZZIRANI, A.A. Características, propriedades e estabilização de dissômicos em Aspergillus nidulans. Piracicaba: USP/ESALQ, 1977. $111 \mathrm{p}$. (Dissertação - Mestrado).

PIZZIRANI-KLEINER, A.A. Efeito do gene bncA1 na formação de conídios de Aspergillus nidulans. Piracicaba: USP/ESALQ, 1981. 141p. (Tese Doutorado).

PIZZIRANI-KLEINER, A.A.; AZEVEDO, J.L. Characterization and genetical analysis of an Aspergillus nidulans strain that produces mutinucleate conidia. Transaction of the British Mycological Society, v.86, p.123-130, 1986a.

PIZZIRANI-KLEINER, A.A.; AZEVEDO, J.L. Effect of the bncA gene on the instability of Aspergillus nidulans. Genetical Research, v.48: p.145$150,1986 b$. 
PONTECORVO, G.; ROPER, J.A.; HEMMONS, L.M.; MacDONALD, K.D.; BUFTON, A.W.J. The genetics of Aspergillus nidulans. Advances in Genetics, v.5, p.141-238, 1953.

TANAKA, Y.; MURATA, N.; KATO, H. Behavior of nuclei and chromosomes during ascus development in the mating between either rice-strain or weeping lovegrass-strain and ragi-strain of Pyricularia. Annual Phythopathology Society Japan, v.45, p.182-191, 1979.

SCHIER, K.; LIESE, R.; FISCHER, R. A Pcl-Like Cyclin of Aspergillus nidulans is Transcriptionally Activated by Developmental Regulators and Is Involved in Sporulation. Molecular and Cellular Biology, v.21, p.4075-4088, 2001.
TIMBERLAKE, W.E.; CLUTTERBUCK, A. Genetic regulation of Conidiation. In: MARTINELLI, S.D.; KINGHORN, J.R. Aspergillus 50 years on. Amsterdam: Elservier, 1994. v.29, cap.16, p.383-427.

YE, X.; LEE, S.; WOLKOW, T.; McGUIRE, S.; HAMER, J.; WOOD, G.; OSMANI, S. Interaction between developmental and cell cycle regulators is required for morphogenesis in Aspergillus nidulans. The EMBO Journal, v.18, p.6994-7001, 1999.

Received February 20, 2003

Accepted April 28, 2004 